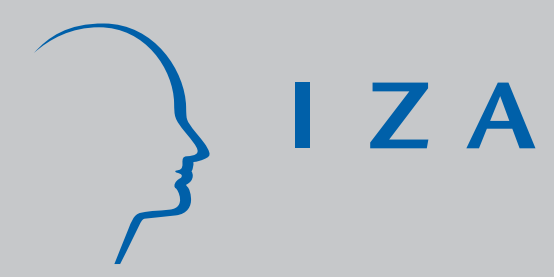

IZA DP No. 2504

How to Help Unemployed Find J obs Quickly: Experimental Evidence from a Mandatory Activation Program

Brian Krogh Graversen

J an C. van Ours

December 2006 


\title{
How to Help Unemployed Find Jobs Quickly: Experimental Evidence from a Mandatory Activation Program
}

\author{
Brian Krogh Graversen \\ Danish National Institute of Social Research \\ Jan C. van Ours \\ Tilburg University, CentER, \\ CEPR and IZA Bonn
}

Discussion Paper No. 2504

December 2006

\author{
IZA \\ P.O. Box 7240 \\ 53072 Bonn \\ Germany \\ Phone: +49-228-3894-0 \\ Fax: +49-228-3894-180 \\ E-mail: iza@iza.org
}

Any opinions expressed here are those of the author(s) and not those of the institute. Research disseminated by IZA may include views on policy, but the institute itself takes no institutional policy positions.

The Institute for the Study of Labor (IZA) in Bonn is a local and virtual international research center and a place of communication between science, politics and business. IZA is an independent nonprofit company supported by Deutsche Post World Net. The center is associated with the University of Bonn and offers a stimulating research environment through its research networks, research support, and visitors and doctoral programs. IZA engages in (i) original and internationally competitive research in all fields of labor economics, (ii) development of policy concepts, and (iii) dissemination of research results and concepts to the interested public.

IZA Discussion Papers often represent preliminary work and are circulated to encourage discussion. Citation of such a paper should account for its provisional character. A revised version may be available directly from the author. 
IZA Discussion Paper No. 2504

December 2006

\section{ABSTRACT \\ How to Help Unemployed Find Jobs Quickly: Experimental Evidence from a Mandatory Activation Program}

This paper investigates how a mandatory activation program in Denmark affects the job finding rate of unemployed workers. The activation program was introduced in an experimental setting where about half of the workers who became unemployed in the period from November 2005 to March 2006 were randomly assigned to the program while the other half was not. It appears that the activation program is very effective. The median unemployment duration of the control group is 14 weeks, while it is 11.5 weeks for the treatment group. The analysis shows that the job finding rate in the treatment group is $30 \%$ higher than in the control group. This result is mainly driven by the more intensive contacts between the unemployed and the public employment service.

JEL Classification: $\quad \mathrm{C} 41, \mathrm{H} 55, \mathrm{~J} 64, \mathrm{~J} 65$

Keywords: $\quad$ unemployment insurance, unemployment duration, experiment

Corresponding author:

Jan C. van Ours

Department of Economics

Tilburg University

P.O. Box 90153

5000 LE Tilburg

The Netherlands

E-mail: vanours@uvt.nl

\footnotetext{
*Financial support from the Danish Social Science Research Council is gratefully acknowledged. The authors thank the Danish National Labor Market Authority for making their data available.
} 


\section{Introduction}

Labor market programs aim at bringing unemployed back to work, preferably quickly. For many programs it is not clear whether or not they are effective and if they are why they are effective. This paper concerns the evaluation of a mandatory activation program in Denmark which was implemented in an experimental setting. In two Danish counties about half of the workers who became unemployed in the period from November 2005 to March 2006 were randomly assigned to the program while the other half got a regular treatment. Randomization is based on birthday. If born in the first half of a particular month an individual is assigned to the treatment group, otherwise the individual belongs to the control group. The experimental set-up enables us to study potential "treatment" effects of the program in great detail.

Our paper contributes to the small literature of experimental studies to assess the effectiveness of labor market programs. ${ }^{1}$ Meyer (1995) presents an overview of unemployment insurance experiments in the U.S. showing that economic incentives affect the speed with which people leave unemployment. The economic incentives not only refer to cash bonuses but also to increased enforcement of work search rules and a strengthening of the work test. Gorter and Kalb (1996) find that intensive counseling and monitoring increase job finding rates of unemployed workers in the Netherlands. Dolton and O'Neill (1996) find effects of the so-called Restart experiments in the UK, where unemployment benefit claimants were obliged to attend meetings with a counselor to receive advice on for example search behavior and training courses. Dolton and O'Neill (2002) report that the interviews reduced the male unemployment rate five years later by 6 percentage points, as compared to a control group for whom participation in the first six-monthly interview took place six months later. Van den Berg and Van der Klaauw (2006) investigate the effect of counseling and monitoring on Dutch UI recipients finding that low-intensity job search assistance programs have at best small effects while high-intensity job search assistance programs may have a more positive effect on the exit rate to work.

Labor market programs often consist of a combination of "carrot" and "stick". The carrot concerns help to the unemployed worker in building up human capital through for example training or work experience programs or help through advice on job search strategies. The

\footnotetext{
${ }^{1}$ See Heckman et al. (1999), Kluve and Schmidt (2002) and Kluve (2006) for general overviews of studies on the effectiveness of active labor market policies.
} 
stick concerns an increase in the cost of being unemployed either through reductions of benefits - benefits sanctions - or through mandatory activities that need time from the unemployed worker. ${ }^{2}$ It could also be that workers increase their job finding rate because of the "threat effect", i.e. they want to avoid having to enter a labor market program. Black et al. (2003) who analyze an experiment on mandatory employment and training programs find that some unemployed workers that are informed about the mandatory character leave unemployment before they have to enter a program. ${ }^{3}$

We analyze data from a Danish experiment in which individuals in the treatment group are confronted with mandatory job search programs, intensive counseling and mandatory training programs. ${ }^{4}$ We investigate whether the treatment effect is different for different groups of individuals, and whether it depends on the duration of unemployment. We also investigate whether there is a difference in treatment effect before, during and after a specific program. And, we try to distinguish between the relative importance of carrot and stick.

We find that the average treatment effect is robust and of the same magnitude for different groups and at different unemployment durations. Furthermore, we find that threat effects are important and we find that job search programs are effective in increasing the job finding rates. ${ }^{5}$ Training programs are not effective over our period of observation. Finally we speculate that the effectiveness of the activation programs is driven more by the stick than by the carrot.

The set-up of the paper is as follows. In section 2 we provide details of the Danish labor market, the policy experiment and our data. In section 3 we present an exploratory analysis in which we investigate whether the probability to leave unemployment in a particular time period is different for the treatment group and the control group. We find that indeed there is

\footnotetext{
${ }^{2}$ There are a few studies on benefit sanctions which all show that the job finding rate of unemployed that are confronted with a benefit reduction increases substantially; see e.g. Jensen et al. (2003), Van den Berg et al. (2004), Abbring et al. (2005) and Lalive et al. (2005).

${ }^{3}$ Geerdsen (2006) identifies the threat effect of Danish labor market programs by exploiting legislative changes in the length of the period in which individuals can receive UI benefits without having to participate in a labor market program. The treat effect results in an almost 100 per cent increase in the job finding rate. Geerdsen and Holm (2007) and Rosholm and Svarer (2004) also find large threat effects.

${ }^{4}$ As will be discussed in detail below under our heading "training programs" there are three types of programs: short work experience, employment subsidy, training and education.

${ }^{5}$ See Blundell et al. (2004) for a - non-experimental - evaluation of a British mandatory job search program with similar results.
} 
a substantial treatment effect. In section 4 we study the treatment effects in more detail using hazard rate models of job finding. Section 5 concludes.

\section{The Danish activation policy}

\subsection{The Danish labor market}

Denmark is one of the smaller countries in the European Union with 5.4 million inhabitants and one of the highest GDP per capita in the world. During recent years Danish labor market policies have received considerable international attention of economists and policy makers because the unemployment rate has been decreasing to a level significantly below the unemployment rate of most other OECD countries while social security schemes have remained relatively generous. In 2005 the OECD standardized unemployment rate in Denmark was 4.8\% while in OECD Europe $8.7 \%$ of the labor force was unemployed.

The terms "flexicurity" - a contraction of flexibility and security - and the "Danish Golden Triangle" are often used to characterize Danish labor market institutions. One side of the triangle consists of flexible rules for hiring and firing of workers. This makes it easy for employers to dismiss workers during recessions and rehire them during booms. Wage earners have security in the form of relatively generous benefits if they become unemployed. This income security is the second side of the triangle. The third side of the triangle is a very active labor market policy which operates according to the "right-and-duty" principle. Unemployed have a right to receive assistance, but at the same time, they have a duty to participate in meetings and active labor market programs when offered in order to remain eligible to unemployment benefits. Since the mid 1990s the use of active labor market programs has been extended considerably, and Denmark is among the countries that have the highest spending on active labor market policies measured as a percentage of GDP (Martin and Grubb (2001)).

Denmark has two types of unemployment benefits: unemployment insurance (UI) benefits and social assistance benefits. Social assistance benefits are means tested, whereas the level of UI benefits is related to previous earnings. Only members of a UI fund can receive UI benefits. Because the UI benefit scheme is more generous than the social assistance benefit scheme, and because the state highly subsidizes UI funds, $80 \%$ of the labor force are members of a UI fund. To be entitled to UI benefits, unemployed individuals must have been members of a UI fund for 
at least 1 year and they must have been employed for at least 52 weeks within the last three years. The maximum duration of UI benefits is four years. ${ }^{6}$ UI benefits are equal to $90 \%$ of previous earnings with a maximum insurable earnings level of approximately $\$ 32,000$ per year. The average replacement rate for UI benefit recipients is $70 \%$. UI benefit recipients have to be activated in ALMPs when they have been unemployed for 1 year. ${ }^{7}$ However they can receive "offers" to participate in ALMPs during the entire unemployment period and even from the very beginning of their unemployment period.

\section{$2.2 \quad$ Set-up of the experiment}

In the experiment half of the newly unemployed UI benefit recipients ${ }^{8}$, who register themselves as unemployed at the Public Employment Service (PES) during the period from November 1, 2005 to February 28, 2006, are assigned to participate in a specially tailored program package. These individuals constitute the treatment group of the experiment. They are all born between the $1^{\text {st }}$ and the $15^{\text {th }}$ of a given month. The other half of the newly unemployed UI benefit recipients, who register themselves as unemployed at the PES during this period receive the normal services from the PES. These individuals constitute the control group. They are born on the $16^{\text {th }}$ or a later day of a given month. Since selection into treatment or control group is based on birth dates within a given month and there is no reason to think that the timing of birth within a particular month is related to job finding rates, the experiment is a truly random. Two Danish counties - Storstrøm County and South Jutland County - participated in the experiment. Each county has approximately 250,000 inhabitants.

The selection of the treatment group and the control group is made in several steps which are described in more detail in Appendix A. For the treatment group the procedure was as follows

\footnotetext{
${ }^{6}$ Individuals who have just finished education or apprenticeship obtain entitlement to UI benefits after a membership period of 1 month without any employment requirement. The UI benefit amount received by these newly educated individuals is $82 \%$ of the UI benefit amount received by UI benefit recipients who fulfil the normal criteria for UI benefit entitlement.

${ }^{7}$ Individuals below 30 years and individuals above 60 years have to be activated in an ALMP after 6 months of unemployment.

${ }^{8}$ Newly unemployed individuals are individuals who begin an unemployment period with a "clean seniority record" in the UI benefit system, i.e. they are eligible for UI benefits for the maximum UI benefit period (4 years) measured from the beginning of their unemployment period.
} 
(see also the schedule presented in Figure 1):

1. When an individual notified the PES that he/she was unemployed, within 1.5 weeks the individual received a letter saying that he/she was selected to participate in the program. The letter also gave a short description of the activities contained in the program.

2. After 5-6 weeks of unemployment individuals had to participate in a job search program which lasts 2 weeks. After the program the individuals had to attend meetings once a week or once every second week. The purpose of the meetings was to assist individuals in their job search and to monitor job search efforts. The individuals could also receive job offers mediated by the PES.

3. Before individuals were unemployed for 4 months they had to receive an offer to participate in an activation program with a duration of at least 3 months. Longer classroom training courses (with a duration of more than 3 months) could not be offered at this stage.

4. Individuals who did not find a job after 6-7 months had to participate in a longer meeting with a case worker and a new job plan was made. The job plan contained a description of the activities to improve the chances of finding a job. All available active measures could be used at this stage including longer education programs.

The services offered to the control group during the early stage of the unemployment period were much less intensive than the services offered to the treatment group. Individuals in the control group typically would have to participate in an activation program after one year of unemployment. UI benefit recipients below 30 and UI benefit recipients above 60 would have to participate in an activation program after 6 months of unemployment though. Job search assistance and monitoring was less intensive and less formalized for the control group than for the treatment group.

\subsection{Available data}

The data used in our analysis are from two different sources. The first data source is the administrative registers of the PES. From these registers we have the following pieces of information for each individual: treatment status (in treatment group or control group), age, sex, immigrant 
status (immigrant or non-immigrant), country of origin, first week of the individuals unemployment spell (can be one of the weeks from the last week of October (week 43) in 2005 to the last but one week of February (week 8) in 2006 i.e. one of the weeks in the assignment period of the experiment), county where the individual lives, and previous occupation. ${ }^{9}$ There is also information about all meetings (type and date) held between the unemployed individuals and caseworkers at the PES or with private contractors. ${ }^{10}$

The second data source is the DREAM database developed by the Danish National Labor Market Authority. From the DREAM database we have detailed weekly information about individuals receipt of different public income transfers. The quality of the information generally is very high. The event history information from the DREAM database is used to determine the duration of unemployment spells and the exit state. For each individual an unemployment spell starts in the week in which the individual became unemployed. The unemployment spell continues until the individual stopped receiving UI benefits (or participate in ALMPs) for four consecutive weeks. ${ }^{11}$

We have data up to mid September 2006. Since there have to be at least 4 weeks without UI benefits (or ALMP participation) to generate an exit from unemployment there are no exits from the unemployment spells during the four last weeks of the observation period. This means that unemployment spells are censored after 43 weeks for those individuals who were assigned into the experiment in the first week of the assignment period. Similarly, unemployment spells of the individuals who were assigned into the experiment in the last week of the assignment period are censored after 26 weeks. Because of the relatively short observation period we only include information on the first unemployment spell of the individuals under study.

\footnotetext{
${ }^{9}$ The occupational classification is based on the name of the UI fund that pays UI benefits to the individual.

${ }^{10}$ In some cases the normal contact sequence between the PES and unemployed individuals are contracted out to an external private contractor.

${ }^{11}$ If a worker became ill his/her benefits changed from unemployment benefits to sickness benefits. We assume that these workers were still unemployed. A worker is assumed to find a job as soon as he or she no longer received benefits payments. Table A2 in Appendix A provides more detailed information about the number of spells and the exit states.
} 


\subsection{Treatment programs}

The unemployed in the treatment group may be confronted with a variety of mandatory activation programs which we grouped in two categories. First there are "job search programs". These programs typically give an overview of available courses and educations, general knowledge about the labor market and specific knowledge about the possibilities to find particular jobs. The participants are also assisted in their job search, and they are trained in job search techniques. The duration of the programs is 2 weeks. Second, there is a group of programs which we labeled "training programs" which consist of three types of programs: short work experience, employment subsidy, and training and education. Short work experience programs are intended to uncover the technical skills, social skills or language skills of the individual. Another purpose is to clarify what would be an appropriate job for the individual. The duration of the program can be up to 4 weeks. Employment subsidy programs aim to train or retrain professional, social or language skills at a workplace. The program can take place in a private firm or in the public sector. During the program period the employers receive a wage subsidy. Training and education programs are intended to upgrade the qualifications (technical, social or language skills) of the participants. For newly unemployed individuals the duration of training/education programs can in general only last up to 6 weeks during the first 12 months of their unemployment spells (6 months for individuals below 30 or above 60 ). ${ }^{12}$ After 12 (or 6) months of unemployment there is greater room for providing longer training/education programs.

Figure 2 shows the weekly transition rates to job search programs for the treated and the non-treated. ${ }^{13}$ Clearly also some of the non-treated flow into job search programs, which were usually substantially shorter than the job search programs the individuals in the treatment group had to attend. In the first weeks of unemployment there is hardly a difference in the inflow into job search programs. After that a lot of the unemployed in the treatment group flow into a job search program. The peak in the inflow rate is between 7 and 9 weeks of unemployment spell. After 15 weeks hardly anyone enters the job search program. By then about $70 \%$ of the treatment group as well as $15 \%$ of the control group have entered a job search program.

\footnotetext{
${ }^{12}$ In cases where it is difficult for the unemployed individuals to find employment within their professional field or in cases where training/education can give individuals employment within a field where there is a lack of labour the 6 week limit can be dropped and the duration can be up to 1 year.

${ }^{13}$ Note that the transition rates in all figures take right-censored durations into account.
} 
Figure 3 shows the weekly transition rates to training programs. Here too, there is inflow of unemployed from the control group. The peak of the inflow of the treatment group is between 18 and 24 weeks. After half a year the cumulative inflow probability for the treatment group is $50 \%$ while it is $20 \%$ for the control group.

The fact that some unemployed from the control group enter labor market programs poses a problem since a simple comparison between the job finding rates of treatment group and control group doesn't take this into account. If we find a positive treatment effect from such a comparison this will be a lower bound of the true effect. ${ }^{14}$ Initially we ignore this problem and focus on the straightforward comparison between treatment group and control group. Later on we will also deal with the issue of control group individuals attending labor market programs.

\section{$3 \quad$ Exploratory analysis}

By way of exploratory analysis we investigate how long workers stay unemployed. Figure 4 presents the survival functions separately for the treatment group and control group. As shown the treatment group leaves unemployment more quickly than the control group. After 3 months $47 \%$ of the control group and $54 \%$ of the treatment group have left unemployment. After 6 months $28 \%$ of the control group is still unemployed while only $21 \%$ of the treatment group is still unemployed. The difference between both survival functions increases up to 13 weeks of unemployment, stays constant until 26 weeks and declines after that. Figure 4 also shows that the median unemployment duration for the control group is about 14 weeks while for the treatment group this is 11.5 weeks.

To get an idea of the treatment effects without introducing too much structure in the empirical model, we perform a logit analysis on the probability of leaving unemployment within a particular time period: $\operatorname{Pr}\left(t<t_{r}\right)=\frac{\exp \left(x^{\prime} \gamma\right)}{1+\exp \left(x^{\prime} \gamma\right)}$ and $\operatorname{Pr}\left(t \geq t_{r}\right)=\frac{1}{1+\exp \left(x^{\prime} \gamma\right)}$, where $t$ refers to the completed duration of unemployment, $t_{r}$ to a threshold $(5,10,15,20 \text {, and } 25 \text { weeks })^{15}, x$ is a vector of explanatory variables, and $\gamma$ a vector of parameters. The explanatory variables concern gender, age, occupation, immigrant status, previous unemployment experience, county and unemployment status (see Appendix B for details). We estimated the parameters using the

\footnotetext{
${ }^{14}$ The employment effects of Danish active labor market programs are generally found to be small or nonexisting, see e.g. Rosholm and Svarer (2004).

${ }^{15}$ Note that every individual was observed for at least 26 weeks.
} 
method of maximum likelihood.

Table 1 shows the estimation results. Estimated over the first 5 weeks there is no significant treatment effect. If the period of observation is expanded the treatment effect becomes significantly different from zero. The speed by which unemployed leave unemployment is also affected by personal characteristics. Males leave unemployment more quickly than females while $50+$ workers stay unemployed longer. Furthermore, there are differences between occupational groups. Also, non-Western immigrants need more time to find a job than non-Western immigrants and native Danes while workers with recent unemployment experience also need more time to find a job. Finally, "excluded workers" have a higher job finding rate. ${ }^{16}$ Many of these workers are unemployed because of bad weather and apparently they leave unemployment quickly - as soon as the weather improves.

The logit estimates suggest that the treatment programs induce workers to leave unemployment more quickly. To understand the mechanisms involved we analyze a more detailed model of unemployment dynamics in the next section.

\section{Hazard rate models}

\subsection{The baseline model}

To understand the mechanisms through which the treatment program affects unemployment dynamics, we analyze job finding rates, which are defined as transitions out of the benefit system. Figure 5 shows the job finding rates separately for the treatment group and the control group. Clearly the job finding rates fluctuate a lot but in the first 6 months of unemployment the job finding rates of the treatment group are always higher than the job finding rate of the control group. After 6 months this difference disappears.

The individual job finding rate at unemployment duration $t$ conditional on observed characteristics $x$ and treatment status $P$ can be specified as a proportional hazard model (see Van den Berg (2001) for details):

$$
\theta(t \mid x, P)=\exp \left(x^{\prime} \beta+\varphi(t)+\delta P\right)
$$

\footnotetext{
${ }^{16}$ Excluded workers are individuals in the treatment group who were excluded from treatment; see Appendix A for details.
} 
where $\beta$ is a vector of parameters representing the effect of personal characteristics and $\varphi(t)$ represents duration dependence in the transition rates

$$
\varphi(t)=\Sigma_{k} \mu_{k} I_{k}(t)
$$

where the $\mu$-parameters describe the stepwise duration dependence with $k(=1, . ., 43)$ as a subscript for the weekly duration intervals and we normalize $\mu_{1}=0$. Furthermore, $P$ is a dummy variable representing whether $(P=1)$ or not $(P=0)$ the individual was assigned to the treatment group. Finally, $\delta$ is our parameter of interest, which indicates whether or not activation influences the job finding rate. In the baseline model we assume that $\delta$ is independent of the duration of unemployment and identical for different groups of workers. Later on, we relax this assumption.

The conditional density function of the completed unemployment duration $t_{u}$ that ended in a transition toward a job can be written as

$$
f\left(t_{u} \mid x, P\right)=\theta\left(t_{u} \mid x, P\right) \exp \left(-\int_{0}^{t_{u}} \theta(s \mid x, P) d s\right)
$$

Since we analyze an inflow sample, the $\log$-likelihood $L$ of the model is straightforward,

$$
L=d \Sigma \log (f)+(1-d) \Sigma \log (1-F)
$$

where $F$ is the distribution function of $f$, and $d$ is a dummy variable with a value of 1 if the worker found a job and a value of 0 if the worker is still unemployed or left unemployment for other reasons.

Table 2 shows the parameter estimates of the baseline model. Consistent with the logit estimates there is a significant treatment effect. On average the job finding rate increases with $21 \%(100 *(\exp (0.19)-1))$. All the signs of the explanatory variables are the same as the estimates of the logit models: Males, workers younger than 50, construction workers (Occupation 3), Danes and workers without recent unemployment experience find a job more quickly than their counterparts. There is a weak tendency towards negative duration dependence in the job finding rate after about 20 weeks. From then on, conditional on their observed characteristics staying unemployed longer reduces the job finding rate.

Table 3 shows the results if we allow the treatment effect to be dependent on personal characteristics, unemployment duration or participation status. For purposes of comparison the 
top row of the first column replicates the parameter estimate of the treatment effect in Table $2 .{ }^{17}$ The parameter estimates show that the treatment effect is robust for different groups of workers. There are no significant differences in treatment effect between males and females. There are differences in treatment effect across age groups but we cannot reject the hypothesis that the treatment effect is constant across ages. ${ }^{18}$ The first column of Table 3 also shows the estimates of the treatment effect if we distinguish between five duration intervals. Then it is clear that the treatment effect is insignificantly different from zero at short unemployment durations (less than 5 weeks) and long unemployment durations (more than 30 weeks). Nevertheless, we still cannot reject the hypothesis that there is one treatment effect.

Furthermore, the first column of Table 3 shows the differences in treatment effect if we distinguish between before - during - after attendance of a program and if we also distinguish between job search and training programs. If unemployed participate in a search program usually about two weeks - this has a positive but insignificant effect on the job finding rate. Apparently participating in such a program does not stimulate nor deter unemployed to find jobs. After they completed the job search program the job finding rates increase 35\%. Participating in training programs has a clear negative effect on the job finding rate. The job finding rate drops $43 \%$. Apparently, once attending such a program the unemployed workers are locked into it. After the program there is a positive effect on the job finding rate but this is insignificantly different from zero. It could be the case that indeed the training programs are not helpful in bringing unemployed back to work more quickly but it is also possible that the period of observation is too short for the treatment effect to materialize.

It makes sense to start investigating the effects of a program after it has finished but one cannot simply ignore the time spent during the program. ${ }^{19}$ To get some idea about the overall effect of a program the bottom lines of Table 3 show parameter estimates if we only distinguish between a before-program effect and "since program start" effects. In this case the program effects are measured from the moment an individual starts in a program; the during and after the program effect are imposed to be the same. Now for job search programs the treatment

\footnotetext{
${ }^{17}$ Because the other parameter estimates are hardly affected by the specification of the treatment effect Table 3 only reports the treatment effects.

${ }^{18}$ The LR test statistic equals 4.8 which is not significant for 4 degrees of freedom.

${ }^{19}$ Richardson and Van den Berg (2001) for example find a positive treatment effect of vocational employment training in Sweden but only if the time spent in these programs is ignored.
} 
effect is of the same size as the before-program effect. The training programs have a significant negative effect on the job finding rate indicating the importance of the locking-in effect.

All in all, from Table 3 we conclude that the overall positive treatment effect consists of two components. First, there is a threat effect causing some unemployed to leave unemployment quickly in order to avoid having to attend intensive programs. Second, after individuals attend job search programs their job finding rate increases substantially. The positive effects of training programs are absent or at least not immediately visible.

\subsection{Additional sensitivity analysis}

In order to investigate the robustness of our results we performed a sensitivity analysis. We allowed the treatment effect to vary weekly and we distinguished between the effects of first, second and third or higher programs and we allowed for duration dependence of the pre-program effect. There are some differences in treatment effect depending on the order of the program and the duration of unemployment when it concerns the pre-program treatment effect but the overall picture does not change. ${ }^{20}$

Furthermore, we allowed for the possibility that unobserved characteristics of unemployed workers - like motivation - affect their job finding rates. To account for this we expand the model and introduce a mixed proportional hazard (MPH) specification. Then, the job finding rate at unemployment duration $t$ conditional on observed characteristics $x$, treatment status $P$ and unobserved characteristics $v$ can be specified as

$$
\theta(t \mid x, P, v)=\exp \left(x^{\prime} \beta+\varphi(t)+\delta P+v\right)
$$

The unobserved components (random effects) are assumed to be independent of $x$ and to follow a discrete distribution with two points of support $v^{a}$ and $v^{b}$

$$
\operatorname{Pr}\left(v=v^{a}\right)=q \quad \operatorname{Pr}\left(v=v^{b}\right)=1-q
$$

in which $q$ has a logit specification with

$$
q=\frac{e^{\alpha}}{1+e^{\alpha}}
$$

\footnotetext{
${ }^{20}$ The parameter estimates are available on request.
} 
The two points of support indicate that conditional on the observed characteristics and the treatment status, there are two types of individuals who differ in their job finding rates. The set-up of the likelihood is similar to equation 4.

The parameter estimates of the MPH model are presented in the second column of Table 3. Conditional on the observed characteristics and the elapsed duration there is a group of $24 \%$ with a lower job finding rate and a group of $76 \%$ with a higher job finding rate. We cannot reject the presence of unobserved heterogeneity. ${ }^{21}$ The introduction of unobserved heterogeneity increases the estimated treatment effect; the job finding rate now increases with $30 \%$ due to the treatment. The differences in treatment effects across various groups, across unemployment durations and across participation states do not change when unobserved heterogeneity is introduced.

\subsection{The treatment effect reconsidered}

Clearly there is a strong treatment effect. There are two potential explanations for this effect. First, it could be that the unemployed workers do not like the treatment, i.e. the treatment increases the cost of being unemployed. In response they increase their search intensity or lower their reservation wages, which increases their job finding rate. If so, the treatment acts as a punishment, a stick. The second explanation for the treatment effect is that unemployed benefit from the job search program so they are able to find a job more quickly. Then, the treatment acts as a help, a carrot. It is difficult to distinguish between the influence of carrot and stick. Nevertheless it is important because if treatment equals stick there could be cheaper alternatives than an intensive activation program to get the same effect.

One way to try to distinguish between the two possible explanations is to look at treatment effects for individuals in the control group. As shown in Figures 1 and 2 some individuals of the control group also enter job search programs and training programs. As indicated before the job search programs attended by individuals of the control group were less intensive. Nevertheless, if a job search program is helping unemployed to find a job more quickly this should be the case irrespective of whether or not the individual is from the treatment group. ${ }^{22}$ Therefore, we also investigate treatment effects for the control group. These additional parameter estimates are

\footnotetext{
${ }^{21}$ The estimation results do not improve if we include three mass points.

${ }^{22}$ Note that in this case we implicitly assume that the entrance into labor market programs of individuals from the control group is non-selective
} 
presented in Table 4. As shown allowing for treatment effects for the control group does not affect the estimates of the treatment effect for the treatment group. For the control group we find no significant positive treatment effects. For training programs we find a significant negative treatment effect. So do the job search programs help unemployed to find a job more quickly? It is not clear. If job search programs would help unemployed to find a job more quickly one would expect similar after-program treatment effect for individuals irrespective if they are from the treatment group or the control group. However, the job search programs attended by individuals of the control group are much shorter than those of the treatment group. The fact that we find a positive after-treatment effect for the treatment group but not for the control group does not necessarily indicate that the job search program is ineffective. Still, it could be that the more intensive contact with the program administrators which is obligatory for individuals in the treatment group and the fear of having to enter a training program are driving the results. Somewhat speculative we conclude that the treatment effect of the job search program is mainly driven by threat and punishment rather than by help.

Another way in which a distinction between the two alternative explanations might be established is by using information about the meetings between the unemployed and program administrators. For the control group the meetings are set up as follows. Not later than 1 month after an individual became unemployed there is a first meeting to deal with the electronic CV of the unemployed. The purpose of the meeting is to secure that the contents of the $\mathrm{CV}$ is appropriate and reflects the desires and abilities of the unemployed. The electronic CV can be used by potential employers. At the first meeting it also has to be discussed how the job search of the individuals can be supported. During the remaining part of the unemployment spell the unemployed have to attend meetings at least every 3 months. The purpose of the meetings is to follow up on individuals job search efforts and to assess what type of ALMP would help the individual closer to a regular job. Since a meeting should be held at least every 3 months the percent attending meetings should not be smaller than 1/13 (7.7\%) every week. As shown in Figure 6 this requirement is clearly fulfilled.

In the treatment group the meeting sequence also has to fulfill the requirements above. In addition to that in the period between the job search program and the training program the unemployed have to attend meetings every week (Storstrøm County) or every second week (South Jutland County). As shown in Figure 6 the meeting frequency remains higher in the 
treatment group after 4 months of unemployment. To what extent job search is discussed at the meetings is not observed in the data. We have information about different meeting types but it is difficult to sort the meeting types according to their focus on job search. Table 5 summarizes the meeting frequencies by quarter. In every quarter the meetings frequency in the treatment group is substantially higher than in the control group.

One of the tasks of the PES is to help employers find appropriate workers. Employers may ask the PES to help recruiting employees. We have also investigated the extent to which the treatment group and control group are referred to these employers. The numbers are calculated by dividing the total number of meetings held in a given week (between the unemployed and employers who posted a job order at the PES) with the number of individuals who are still unemployed in this week. ${ }^{23}$ As shown in Table 5 the average meetings rate between unemployed and employers is very low - on average $0.5 \%$ in the first 9 months of unemployment. And, there does not appear to be a difference between treatment and control group. Hence the treatment group does not seem to receive more job offers than the control group when we are only looking at job orders received by the PES. ${ }^{24}$

\section{Conclusions}

Labor market programs often combine elements of help and activation, i.e. carrot and stick. The help component may increase human capital of participants or assist them in finding a job; the activation component may stimulate unemployed to find a job more quickly because of the increased costs of being unemployed. This paper investigates how programs of job search assistance and training help unemployed to find a job more quickly. The analysis is based on data collected during a field experiment in Denmark. Over a period time workers that became unemployed in two Danish counties were randomly assigned to a treatment group which had to attend labor market programs and a control group which didn't have to do that. The treatment program consisted of an intensive two weeks job search course. After this course the unemployed had to attend regular meetings with PES staff where advice was given about search strategies and search efforts were monitored. Furthermore, unemployed could be assigned to training

\footnotetext{
${ }^{23}$ We do not know whether the meeting actually resulted in a job match/employment

${ }^{24}$ In fact, most jobs in Denmark are filled without the PES being directly involved.
} 
programs.

The main result of the analysis is that assignment to the treatment group increased the job finding rate of unemployed workers on average with $30 \%$. This result is robust and of the same magnitude for different groups of workers. When comparing programs we find substantial differences. Training programs did not bring unemployed back to work more quickly, probably because of a locking-in effect. Once in a training program job finding rates decreased substantially. Whether there are more positive long-run effects of training programs is not clear. The increase in job finding rates of the individuals in the treatment group is mainly due to two effects. The first effect concerns the high job finding rate before any program is attended. Apparently some individuals want to avoid going into a program and therefore leave unemployment quickly. The second effect concerns the after-program effect. Once an individual of the treatment group finishes a job search program the job finding rate is higher for three reasons. First, the job search course may have been helpful in more efficient job search. Second, the threat of having to attend training programs may have stimulated unemployed to find a job more quickly. Third, the intensive meetings between unemployed and program administrators increased the costs of being unemployed but may also have assisted the unemployed in their job search. The first reason is a carrot, the second is a stick, and the third is a mixture of the two. Somewhat speculative we conclude that it is in particular the stick of the treatment that causes the positive effect on the job finding rate. 


\section{References}

[1] Abbring, J.H., G.J. van den Berg and J.C. van Ours (2005) The effect of unemployment insurance sanctions on the transition rate from unemployment to employment, Economic Journal, 115, 602-630.

[2] Black, D.A., J.A. Smith, M.C. Berger and B.J. Noel (2003) Is the threat of reemployment services more effective than the services themselves? Evidence from random assignment in the UI system, American Economic Review, 93, 1313-1327.

[3] Blundell, R., M. Costa Dias, C. Meghir and J. Van Reenen (2004) Evaluating the employment impact of a mandatory job search program, Journal of the European Economic Association, 2, 569-606.

[4] Dolton, P. and D. O'Neill (1996) Unemployment duration and the Restart effect: some experimental evidence, Economic Journal, 106, 387-400.

[5] Dolton, P. and D. O'Neill (2002) The long-run effects of unemployment monitoring and work-search programs: experimental evidence from the United Kingdom, Journal of Labor Economics, 20, 381-403.

[6] Geerdsen, L.P. (2006) Is there a threat effect of labor market programs? A study of ALMP in the Danish UI system, Economic Journal, 116, 738-750.

[7] Geerdsen, L.P. and A. Holm (2007) Duration of UI periods and the perceived threat effect from labor market programs, Labour Economics, forthcoming.

[8] Gorter, C. and G.R.J. Kalb (1996) Estimating the effect of counseling and monitoring the unemployed using a job search model, Journal of Human Resources, 31, 590-610.

[9] Heckman, J.J., R.J. Lalonde and J.A. Smith (1999) The economics and econometrics of active labor market programs, in: Ashenfelter, O. and D. Card (eds.) Handbook of Labor Economics, Volume 3A, Amsterdam, North-Holland.

[10] Jensen, P., M. Rosholm and M. Svarer (2003) The response of youth unemployment to benefits, incentives, and sanctions, European Journal of Political Economy, 19, 301-316. 
[11] Kluve, J. and C.M. Schmidt (2002) Can training and employment subsidies combat European unemployment? Economic Policy, 35, 411-448.

[12] Kluve, J. (2006) The effectiveness of European active labor market policy, Working Paper, no. 2018, IZA, Bonn.

[13] Lalive, R., J.C. van Ours, and J. Zweimüller (2005) The effects of benefit sanctions on the duration of unemployment, Journal of the European Economic Association, 3, 1386-1417.

[14] Martin, J.P. and D. Grubb (2001) What works and for whom: A review of OECD countries experiences with active labour market policies, Swedish Economic Policy Review, 8, 9-56.

[15] Meyer, B.D. (1995) Lessons from the U.S. unemployment insurance experiments, Journal of Economic Literature 33 (1): 91-131.

[16] Richardson, K. and G.J. van den Berg (2001) The effect of vocational employment training on the individual transition rate from unemployment to work, Swedish Economic Policy Review, 8, 175-213.

[17] Rosholm, M. and M. Svarer (2004) Estimating the threat effect of active labor market programs, Working Paper, 2004-6, Department of Economics, University of Aarhus.

[18] Van den Berg, G. J. (2001) Duration models: specification, identification, and multiple durations, in: Heckman, J.J. and E. Leamer (eds) Handbook of Econometrics, Volume V, North-Holland.

[19] Van den Berg, G.J. and B. van der Klaauw (2006) Counseling and monitoring of unemployed workers: theory and evidence from a controlled social experiment, International Economic Review, 47, 895-936.

[20] Van der Klaauw, B., G.J. van den Berg and J.C. van Ours (2004) Punitive sanctions and the transition rate from welfare to work, Journal of Labor Economics, 22, 211-241. 
Figure 1: Timing of various activities for the treatment group - from the start of the unemployment spell

\begin{tabular}{llllll}
$\begin{array}{l}\text { Start } \\
\begin{array}{l}\text { unempl. } \\
\text { spell }\end{array}\end{array}$ & $\begin{array}{l}\text { Letter to } \\
\text { treatment group } \\
\text { with details of } \\
\text { the program }\end{array}$ & $\begin{array}{l}\text { Job search } \\
\text { program } \\
(2 \text { weeks })\end{array}$ & $\begin{array}{l}\text { Intensive } \\
\text { contact with } \\
\text { PES }\end{array}$ & $\begin{array}{l}\text { Activation } \\
\text { program }\end{array}$ & $\begin{array}{l}\text { Reassignment } \\
\text { of individuals } \\
\text { who have not } \\
\text { yet found a job }\end{array}$ \\
\hline & & & & & \\
\hline & 1.5 weeks & $5-6$ weeks & & 4 months & $6-7$ months
\end{tabular}


Figure 2: Exit rates to job search programs

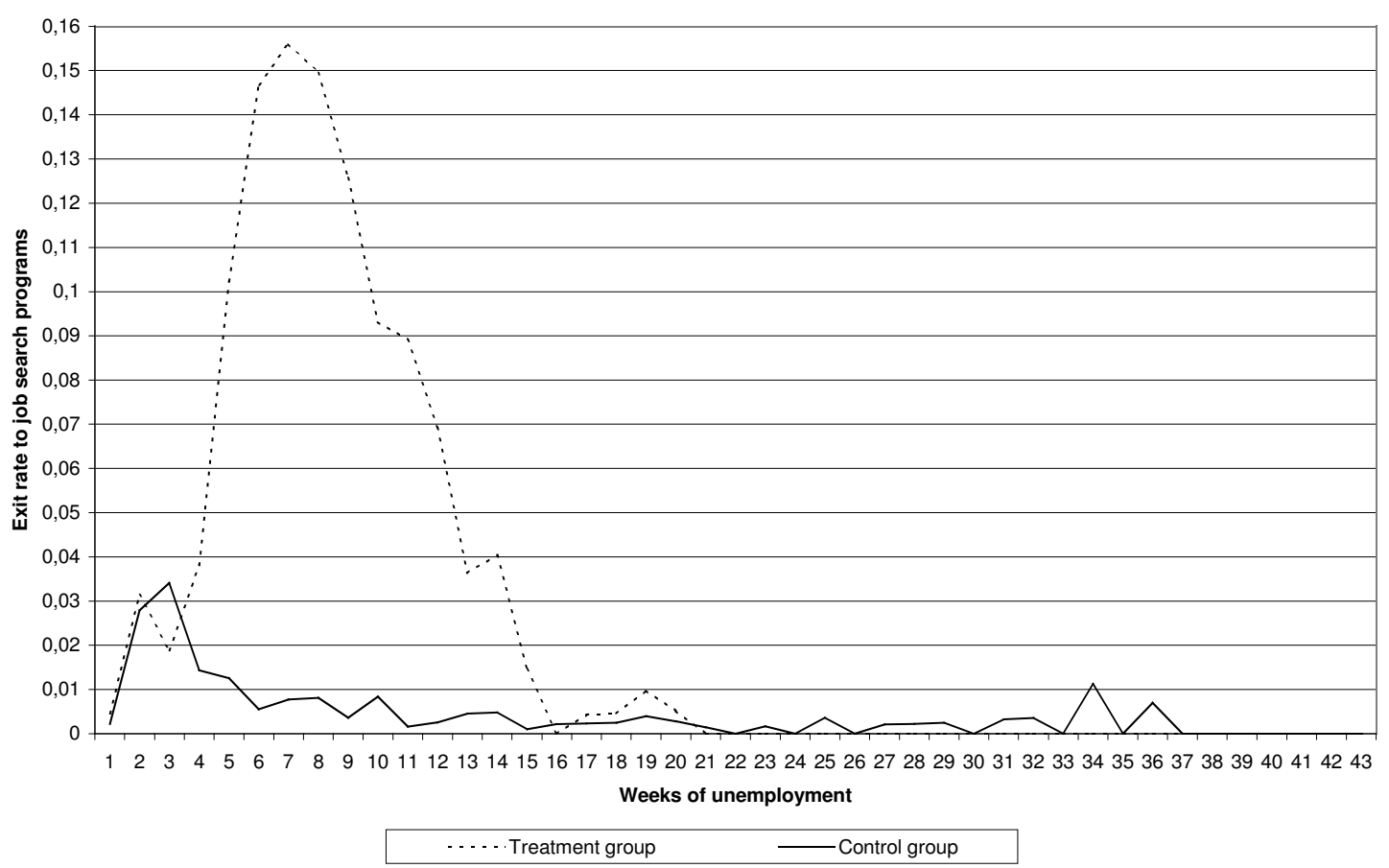


Figure 3: Exit rates to training programs

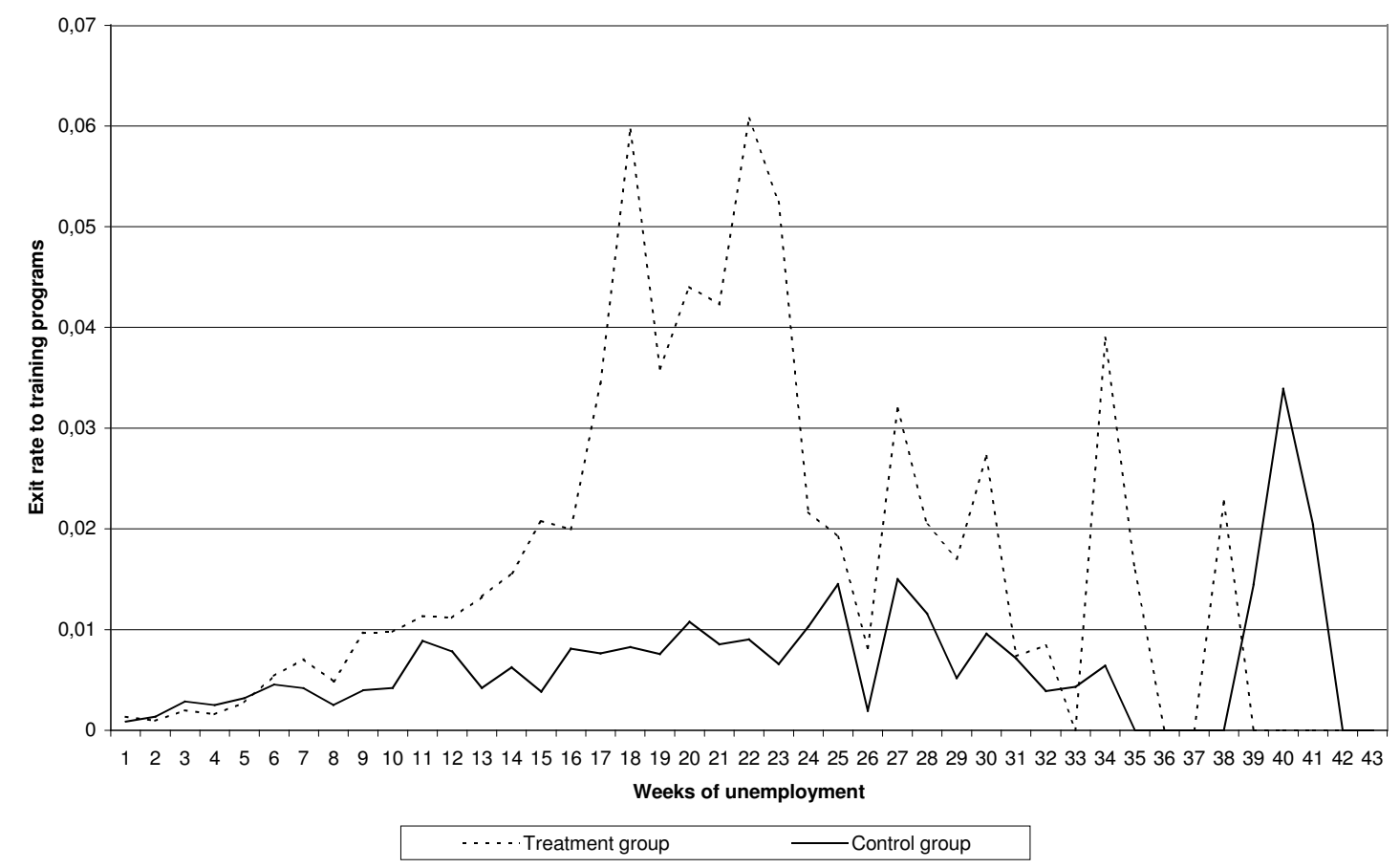


Figure 4: Survivor functions

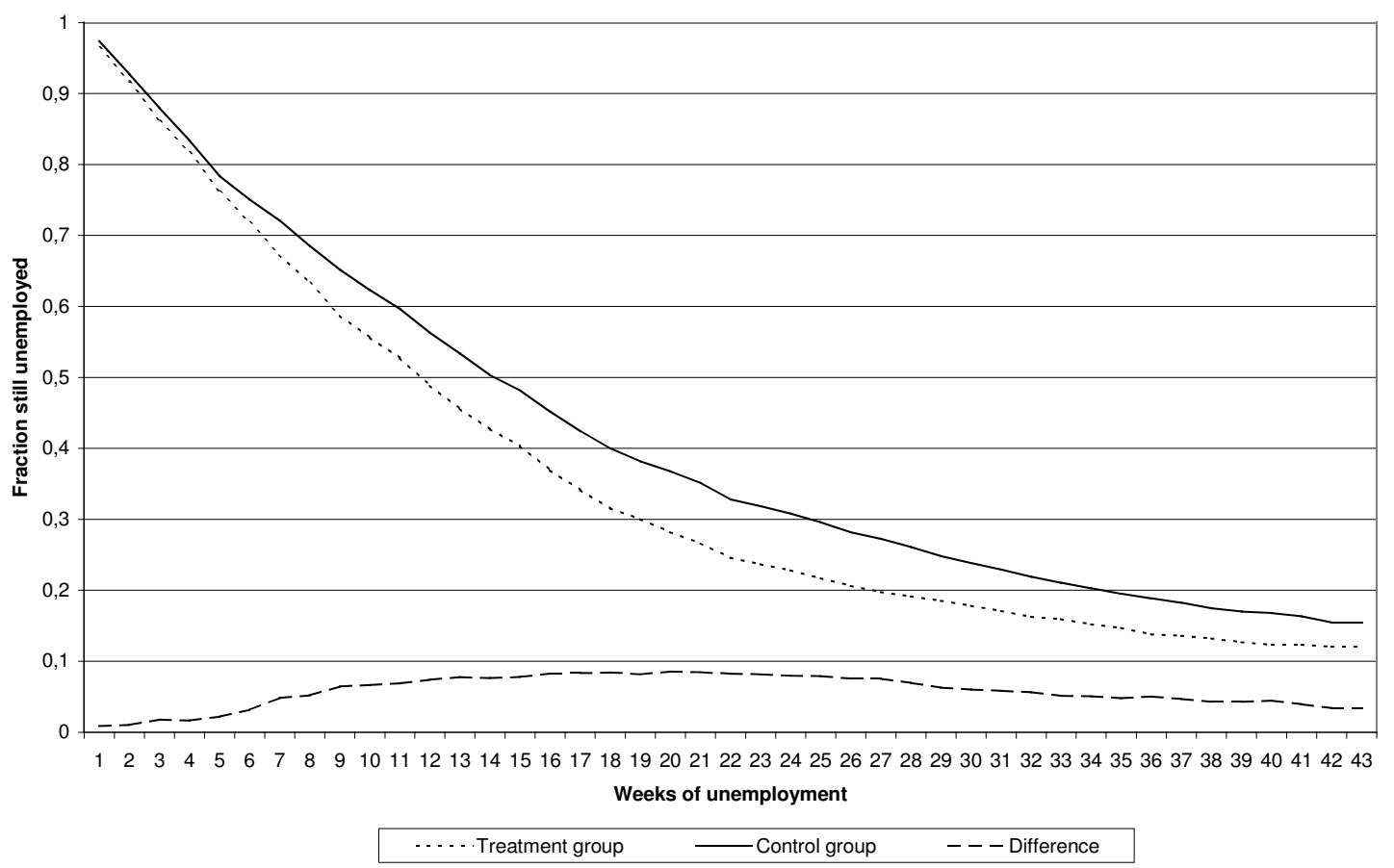


Figure 5: Weekly job finding rates

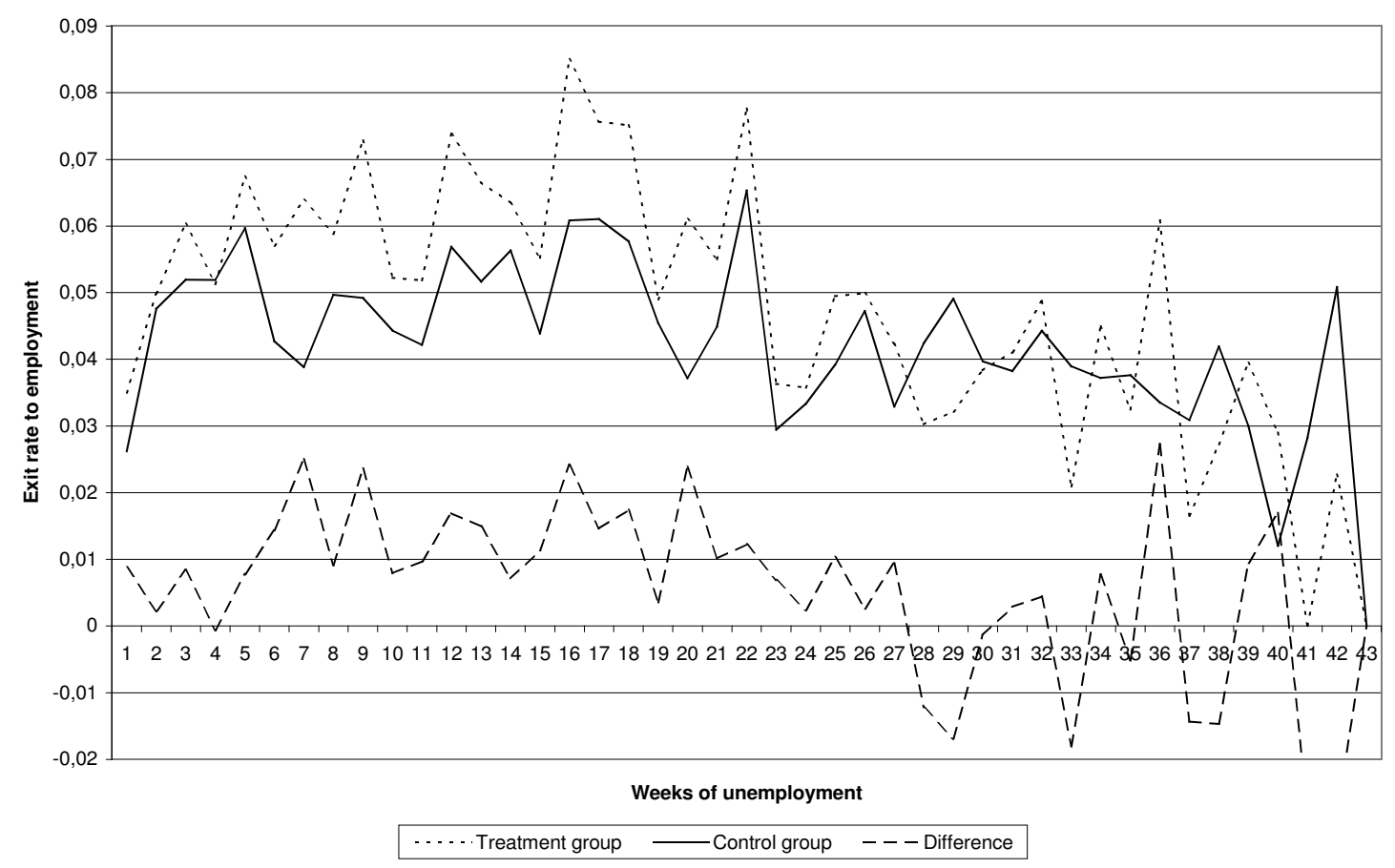


Figure 6: Weekly meetings (\% per week)

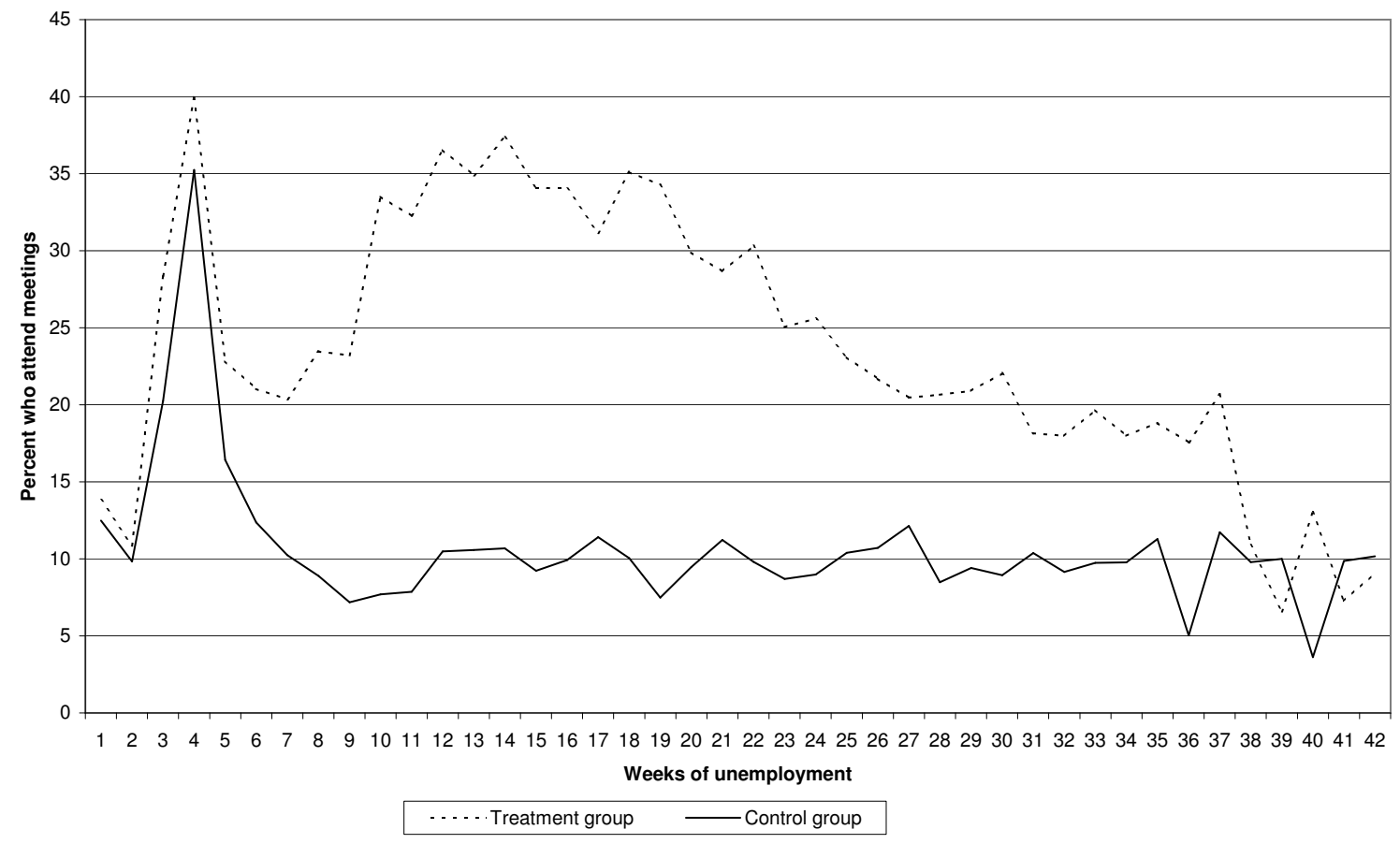


Table 1: Probability of leaving unemployment within a particular period of time; parameter estimates logit models

\begin{tabular}{|l|cllll|}
\hline & \multicolumn{5}{|c|}{ Period of time (weeks) } \\
\cline { 2 - 6 } & 5 & \multicolumn{5}{c}{15} & 20 & 25 \\
\hline Treatment effect & $0.11(0.08)$ & $0.29(0.07) * *$ & $0.36(0.07) * *$ & $0.35(0.07) * *$ & $0.34(0.07) * *$ \\
\hline Explanatory variables & \multicolumn{7}{|c}{. } \\
\hline Male & $0.39(0.10) * *$ & $0.65(0.08) * *$ & $0.63(0.08) * *$ & $0.76(0.08) * *$ & $0.79(0.08) * *$ \\
Age 30-39 & $0.17(0.11)$ & $0.13(0.10)$ & $0.15(0.10)$ & $0.23(0.10)$ & $0.24(0.10)$ \\
Age 40-49 & $0.11(0.11)$ & $-0.17(0.09)$ & $0.03(0.09)$ & $0.15(0.10)$ & $0.26(0.10)$ \\
Age 50-59 & $-0.15(0.12)$ & $-0.41(0.10) * *$ & $-0.45(0.10) * *$ & $-0.34(0.10) * *$ & $-0.32(0.10) * *$ \\
Age 60+ & $-0.17(0.24)$ & $-0.77(0.21) * *$ & $-0.85(0.20) * *$ & $-0.65(0.20) * *$ & $-0.62(0.20) * *$ \\
Occupation 1 & $-1.04(0.34) * *$ & $-0.69(0.24) * *$ & $-0.82(0.22) * *$ & $-0.94(0.22) * *$ & $-0.80(0.22) * *$ \\
Occupation 2 & $-0.16(0.17)$ & $-0.03(0.14)$ & $-0.23(0.14)$ & $-0.47(0.14) * *$ & $-0.48(0.14) * *$ \\
Occupation 3 & $0.79(0.13) * *$ & $1.14(0.14) * *$ & $0.79(0.15) * *$ & $0.88(0.19) * *$ & $0.86(0.21) * *$ \\
Occupation 4 & $-0.70(0.17) * *$ & $-0.16(0.13)$ & $-0.29(0.12) * *$ & $-0.64(0.12) * *$ & $-0.66(0.12) * *$ \\
Occupation 5 & $-0.65(0.21) * *$ & $-0.74(0.18) * *$ & $-0.80(0.16) * *$ & $-1.19(0.16) * *$ & $-1.14(0.16) * *$ \\
Occupation 6 & $-0.42(0.13) * *$ & $-0.22(0.11) * *$ & $-0.28(0.10) * *$ & $-0.37(0.11) * *$ & $-0.50(0.11) * *$ \\
Occupation 7 & $0.02(0.17)$ & $0.25(0.14) *$ & $-0.18(0.14)$ & $-0.32(0.14) * *$ & $-0.34(0.14) * *$ \\
Occupation 8 & $-0.21(0.17)$ & $0.00(0.15)$ & $-0.10(0.15)$ & $-0.43(0.16) * *$ & $-0.45(0.17) * *$ \\
Occupation 9 & $-0.22(0.24)$ & $-0.01(0.21)$ & $-0.18(0.20)$ & $-0.63(0.20) * *$ & $-0.47(0.21) * *$ \\
Occupation 10 & $-0.40(0.22) *$ & $-0.20(0.18)$ & $-0.31(0.17) *$ & $-0.61(0.18) * *$ & $-0.81(0.18) * *$ \\
Immigr. Western & $-0.01(0.25)$ & $-0.18(0.22)$ & $-0.12(0.21)$ & $-0.10(0.22)$ & $-0.17(0.22)$ \\
Immigr. non-Western & $-0.01(0.19)$ & $-0.45(0.18) * *$ & $-0.38(0.16) * *$ & $-0.47(0.17) * *$ & $-0.60(0.17) * *$ \\
Previous unempl. 1 & $-0.85(0.19) * *$ & $-0.79(0.16) * *$ & $-0.89(0.15) * *$ & $-0.86(0.15) * *$ & $-0.64(0.15) * *$ \\
Previous unempl. 2 & $0.09(0.19)$ & $-0.19(0.16)$ & $-0.25(0.16)$ & $-0.47(0.16) * *$ & $-0.31(0.16) *$ \\
Previous unempl. 3 & $-0.39(0.17) * *$ & $-0.28(0.14) * *$ & $-0.40(0.13)$ & $-0.13(0.13)$ & $-0.17(0.14)$ \\
Storstrøm County & $0.02(0.08)$ & $0.00(0.07)$ & $-0.01(0.07)$ & $-0.01(0.07)$ & $-0.03(0.07)$ \\
Excluded Member & $1.04(0.27) * *$ & $0.56(0.26) * *$ & $0.45(0.26) *$ & $0.46(0.27) *$ & $0.49(0.29) *$ \\
\hline
\end{tabular}

Note: In the estimates also a constant is included and weekly dummy variables for the week of inflow into unemployment; these parameter estimates are not reported (but they are available on request); standard errors in parentheses; a ${ }^{* *}(*)$ indicates significance at a $95 \%(90 \%)$ level. 
Table 2: Parameter estimates baseline hazard rate model

\begin{tabular}{|c|c|c|c|}
\hline Treatment & $0.19(0.04)^{* *}$ & & \\
\hline Constant & $-3.62(0.14)^{* *}$ & 8-9 weeks & $0.88(0.12)^{* *}$ \\
\hline Male & $0.42(0.04)^{* *}$ & 9-10 weeks & $0.66(0.13)^{* *}$ \\
\hline Age 30-39 & $0.01(0.05)$ & 10-11 weeks & $0.65(0.13)^{* *}$ \\
\hline Age $40-49$ & $-0.03(0.05)$ & 11-12 weeks & $0.99(0.12)^{* *}$ \\
\hline Age 50-59 & $-0.26(0.05)^{* *}$ & 12-13- weeks & $0.92(0.13)^{* *}$ \\
\hline Age $60+$ & $-0.24(0.11)^{* *}$ & 13-14 weeks & $0.95(0.13)^{* *}$ \\
\hline Occupation 1 & $-0.50(0.12)^{* *}$ & 14-15 weeks & $0.77(0.14)^{* *}$ \\
\hline Occupation 2 & $-0.33(0.08)^{* *}$ & 15-16 weeks & $1.18(0.13)^{* *}$ \\
\hline Occupation 3 & $0.59(0.07)^{* *}$ & 16-17 weeks & $1.13(0.13)^{* *}$ \\
\hline Occupation 4 & $-0.40(0.07)^{* *}$ & 17-18 weeks & $1.11(0.14)^{* *}$ \\
\hline Occupation 5 & $-0.62(0.09)^{* *}$ & 18-19 weeks & $0.78(0.14)^{* *}$ \\
\hline Occupation 6 & $-0.29(0.06)^{* *}$ & 19-20 weeks & $0.80(0.15)^{* *}$ \\
\hline Occupation 7 & $-0.27(0.08)^{* *}$ & 20-21 weeks & $0.85(0.16)^{* *}$ \\
\hline Occupation 8 & $-0.17(0.08)^{* *}$ & 21-22 weeks & $1.23(0.14)^{* *}$ \\
\hline Occupation 9 & $-0.27(0.11)^{* *}$ & $22-23$ weeks & $0.43(0.19)^{* *}$ \\
\hline Occupation 10 & $-0.41(0.10)^{* *}$ & 23-24 weeks & $0.50(0.19)^{* *}$ \\
\hline Immigrant Western & $-0.10(0.12)$ & 24-25 weeks & $0.76(0.17)^{* *}$ \\
\hline Immigrant non-Western & $-0.31(0.09)^{* *}$ & 25-26 weeks & $0.86(0.17)^{* *}$ \\
\hline Previous unemployed 1 & $-0.57(0.08)^{* *}$ & 26-27 weeks & $0.57(0.19)^{* *}$ \\
\hline Previous unemployed 2 & $-0.10(0.09)$ & 27-28 weeks & $0.59(0.20)^{* *}$ \\
\hline Previous unemployed 3 & $-0.16(0.07)^{* *}$ & 28-29 weeks & $0.73(0.19)^{* *}$ \\
\hline Storstrøm County & $0.04(0.04)$ & 29-30 weeks & $0.64(0.22)^{* *}$ \\
\hline Excluded Member & $0.36(0.13)^{* *}$ & 30-31 weeks & $0.68(0.22)^{* *}$ \\
\hline \multicolumn{2}{|l|}{ Duration dependence } & 31-32 weeks & $0.87(0.22)^{* *}$ \\
\hline $0-1$ weeks & - & $32-33$ weeks & $0.52(0.27)^{* *}$ \\
\hline 1-2 weeks & $0.49(0.11)^{* *}$ & 33-34 weeks & $0.78(0.27)^{* *}$ \\
\hline $2-3$ weeks & $0.67(0.11)^{* *}$ & $34-35$ weeks & $0.72(0.31)^{* *}$ \\
\hline 3-4 weeks & $0.62(0.11)^{* *}$ & 35-36 weeks & $0.96(0.28)^{* *}$ \\
\hline 4-5 weeks & $0.85(0.11)^{* *}$ & 36-37 weeks & $0.25(0.40)$ \\
\hline 5-6 weeks & $0.63(0.12)^{* *}$ & 37-38 weeks & $0.75(0.35)^{* *}$ \\
\hline 6-7 weeks & $0.67(0.12)^{* *}$ & 38-39 weeks & $0.60(0.43)$ \\
\hline 7-8 weeks & $0.75(0.12)^{* *}$ & 39-43 weeks & $0.25(0.35)$ \\
\hline -Loglikelihood & & 13745.0 & \\
\hline
\end{tabular}

Note: In the estimates also dummy variables for the week of inflow into unemployment; these parameter estimates are not reported (but they are available on request); standard errors in parentheses; a ${ }^{* *}(*)$ indicates significance at a $95 \%(90 \%)$ level. 
Table 3: Parameter estimates hazard rate models with alternative specifications for the treatment effect and the introduction of unobserved heterogeneity - hazard rate models

\begin{tabular}{|c|c|c|c|c|}
\hline & \multicolumn{2}{|c|}{$\begin{array}{r}\text { No unobserved heterogeneity } \\
\text {-Loglikelihood }\end{array}$} & \multicolumn{2}{|c|}{$\begin{array}{l}\text { Unobserved heterogeneity } \\
\text {-Loglikelihood }\end{array}$} \\
\hline Average effect & $0.19(0.04)^{* *}$ & 13745.0 & $0.26(0.04)^{* *}$ & 13711.3 \\
\hline \multicolumn{5}{|l|}{ By gender } \\
\hline Men & $0.18(0.04)^{* *}$ & & $0.25(0.06)^{* *}$ & \\
\hline Women & $0.21(0.06)^{* *}$ & 13744.8 & $0.29(0.07)^{* *}$ & 13711.4 \\
\hline \multicolumn{5}{|l|}{ By age group } \\
\hline Age $<30$ & $0.23(0.07)^{* *}$ & & $0.32(0.09)^{* *}$ & \\
\hline Age $30-39$ & $0.12(0.07)^{*}$ & & $0.21(0.08)^{* *}$ & \\
\hline Age $40-49$ & $0.14(0.07)^{* *}$ & & $0.16(0.09)^{*}$ & \\
\hline Age $50-59$ & $0.30(0.07)^{* *}$ & & $0.37(0.09)^{* *}$ & \\
\hline Age $60+$ & $0.24(0.21)$ & 13742.6 & $0.31(0.26)$ & 13709.8 \\
\hline \multicolumn{5}{|l|}{ By unemployment duration } \\
\hline 1-4 weeks & $0.10(0.08)$ & & $0.12(0.08)$ & \\
\hline 5-9 weeks & $0.29(0.07)^{* *}$ & & $0.32(0.07)^{* *}$ & \\
\hline 10-17 weeks & $0.23(0.07)^{* *}$ & & $0.32(0.07)^{* *}$ & \\
\hline 18-30 weeks & $0.15(0.08)^{*}$ & & $0.33(0.09)^{* *}$ & \\
\hline$\geq 30$ weeks & $-0.02(0.17)$ & 13741.9 & $0.20(0.19)$ & 13708.4 \\
\hline \multicolumn{5}{|l|}{ By participation status - I } \\
\hline Before participation & $0.25(0.05)^{* *}$ & & $0.27(0.05)^{* *}$ & \\
\hline During job search program & $0.14(0.10)$ & & $0.18(0.10)$ & \\
\hline After job search program & $0.30(0.05)^{* *}$ & & $0.36(0.06)^{* *}$ & \\
\hline During training program & $-0.56(0.11)^{* *}$ & & $-0.56(0.12)^{* *}$ & \\
\hline After training program & $0.20(0.14)$ & 13708.1 & $0.27(0.14)^{*}$ & 13680.9 \\
\hline \multicolumn{5}{|l|}{ By participation status - II } \\
\hline Before participation & $0.26(0.04)^{* *}$ & & $0.29(0.05)^{* *}$ & \\
\hline Job search program & $0.27(0.05)^{* *}$ & & $0.32(0.06)^{* *}$ & \\
\hline Training program & $-0.33(0.09)^{* *}$ & 13719.4 & $-0.30(0.10)^{* *}$ & 13691.8 \\
\hline
\end{tabular}

Note: The parameter estimates for the explanatory variables, the weeks of inflow and the duration dependence parameters are not reported because they are very similar to the estimates in Table 2; discrete unobserved heterogeneity with two points of support; standard errors in parentheses; a ${ }^{* *}(*)$ indicates significance at a $95 \%(90 \%)$ level. 
Table 4: Parameter estimates treatment effects for the treatment group and the control group - hazard rate models

\begin{tabular}{|l|c|c|}
\hline & $\begin{array}{c}\text { No unobserved } \\
\text { heterogeneity }\end{array}$ & $\begin{array}{c}\text { Unobserved } \\
\text { heterogeneity }\end{array}$ \\
\hline Treatment group & & \\
\hline Before participation & $0.23(0.05)^{* *}$ & $0.25(0.05)^{* *}$ \\
During job search program & $0.11(0.10)$ & $0.14(0.10)$ \\
After job search program & $0.26(0.05)^{* *}$ & $0.31(0.06)^{* *}$ \\
During training program & $-0.62(0.11)^{* *}$ & $-0.63(0.12)^{* *}$ \\
After training program & $0.14(0.14)$ & $0.19(0.14)$ \\
\hline Control group & & \\
\hline During job search program & $-0.10(0.22)$ & $-0.11(0.22)$ \\
After job search program & $-0.05(0.09)$ & $-0.09(0.11)$ \\
During training program & $-0.92(0.18)^{* *}$ & $-1.07(0.19)^{* *}$ \\
After training program & $0.03(0.18)$ & $-0.15(0.22)$ \\
\hline -Loglikelihood & 13688.0 & 13658.8 \\
\hline
\end{tabular}

Note: The parameter estimates for the explanatory variables, the weeks of inflow and the duration dependence parameters are not reported because they are very similar to the estimates in Table 2; discrete unobserved heterogeneity with two points of support; standard errors in parentheses; a ${ }^{* *}(*)$ indicates significance at a $95 \%(90 \%)$ level. 
Table 5: Meetings between unemployed and program administrators; average weekly frequency $(\%)$

\begin{tabular}{|l|ccc|}
\hline $\begin{array}{l}\text { Weeks of } \\
\text { unemployment }\end{array}$ & $\begin{array}{c}\text { Treatment } \\
\text { Group }\end{array}$ & $\begin{array}{c}\text { Control } \\
\text { Group }\end{array}$ & Difference \\
\hline & \multicolumn{3}{|c|}{ All meetings } \\
$0-13$ & 26.2 & 13.0 & 13.2 \\
$14-26$ & 30.0 & 9.9 & 20.1 \\
$27-39$ & 17.9 & 9.7 & 8.2 \\
Average & 25.0 & 10.9 & 14.1 \\
\hline & \multicolumn{3}{|c}{ Meetings } \\
$0-13$ & 0.6 & 0.5 & 0.1 \\
$14-26$ & 0.7 & 0.7 & 0.1 \\
$27-39$ & 0.2 & 0.4 & -0.2 \\
Average & 0.5 & 0.5 & 0.0 \\
\hline
\end{tabular}

Note: All meetings concern meetings between unemployed and case workers; meetings with employers concern meeting between unemployed and employers for vacancies mediated by the PES; presented are percentages calculated as the number of meetings held in a given week divided by the number of individuals who are still unemployed in this week. 


\section{Appendices}

\section{A Details about the data}

The selections of the treatment group and the control group are made in three steps. First, every week (from week 44 in 2005 to week 9 in 2006), generally on a Tuesday, newly unemployed individuals who registered themselves as unemployed at the PES during the previous week and who were still unemployed on Friday in the previous week were selected to participate in the experiment. For example an individual who became unemployed in week 43 of 2005 and who were still unemployed on Friday 28 October 2005 was selected to participate in the experiment on Tuesday 1 November 2005. Hence the treatment group and the control group consist of newly unemployed individuals who registered at the PES during the weeks from week 43 in 2005 to week 8 in 2006. Second, individuals who (in the administrative registers) are unemployed because of bad weather or under some work sharing arrangement are excluded from the experiment. Individuals who find a job before the selection process is accomplished are excluded from the experiment as well. Third, individuals born between the $1^{\text {st }}$ and the $15^{\text {th }}$ of a given month are assigned into the treatment group. Other individuals are assigned into the control group. Thus, 2542 individuals were assigned to the treatment group and 2638 individuals to the control group. We do, however, not use the full sample of individuals. Some individuals were not correctly assigned according to their birth date. There were 15 individuals registered as belonging to the control group which should have been in the treatment group. And, 12 individuals registered as belonging to the treatment group should have been in the control group. Whether the individuals where in fact given the correct treatment (treatment or no treatment) we do not know. We excluded these individuals (27) from the empirical analysis.

Also, the discarding of individuals from the experiment who are unemployed because of bad weather or who are under some work sharing arrangement were not done with 100 percent precision. Some individuals who were registered to be unemployed because of bad weather or work sharing arrangements appeared in the treatment group. We excluded 43 individuals because they were unemployed for these reasons. We also exclude 37 individuals who move abroad after they were selected to participate in the experiment or because they died. 
Finally, we excluded 553 individuals who did not receive UI benefits within the first 6 weeks after the date when they were registered as unemployed at the PES. One reason for this selection criterion is that information on UI benefits is used to determine the duration of unemployment spells. If an individual never received UI benefits we will not be able to determine when the unemployment spell ended. There are several reasons why not all unemployed individuals receive UI benefits from the beginning of the unemployment spell. The first two days of an unemployment spell the unemployed individuals do not receive UI benefits from the UI funds but from the previous employer. Information about these benefits paid by the employer is not included in our data. Individuals who had just completed an education that made them eligible for UI benefits can only receive UI benefits one month after they have ended their education. When an individual voluntarily quits a job and becomes unemployed he/she can not receive UI benefits the first 3 weeks after the resignation. The disadvantage of excluding individuals that did not receive UI benefits shortly after becoming unemployed is of course that many individuals with very short unemployment spells are not included in the analysis. The transition rate into employment is hence downward biased during the first few weeks of the unemployment spells. More individuals are excluded from the control group than from the treatment group. This may be because the program administrators have been more careful with excluding individuals who should not be a part of the experiment when they were looking at the treatment group than when they were looking at the control group. It would have been problematic if we excluded more individuals from the treatment group than from the control group. This might have indicated that part of the program effect would not appear in our estimates because treatment group members to a larger extent than control group members found jobs before they became eligible for UI benefits. Another reason for excluding individuals who did not receive UI benefits shortly after becoming unemployed is that a significant fraction of the individuals selected into the experiment were actually not eligible for UI benefits and should not have been included in the experiment (one reason for the incorrect assignment into the experiment is that the information available for the program administrators when the selection process was made was not always of sufficient quality - part of the information needed for the selection process was supplied by the unemployed individuals).

The steps of going from the gross sample to the net sample are the following:

1. Person is from one of the two regions and are selected to participate in the experiment.

2. Correct assignment into treatment and control according to the civil registration number.

3. Person is not unemployed because of bad weather or because he/she is under some work sharing arrangement (according to information in administrative registers).

4. Person does not die and does not move abroad after the first day of unemployment.

5. Person receives UI benefits not later than 6 weeks after having registered himself/herself as unemployed at the PES. 
Table A1 quantifies these steps:

Table A1 From gross to net dataset

\begin{tabular}{|l|ccc|}
\hline \multirow{2}{*}{ Steps } & Numbers & & \\
\cline { 2 - 4 } & $\begin{array}{c}\text { Treatment } \\
\text { group }\end{array}$ & $\begin{array}{c}\text { Control } \\
\text { group }\end{array}$ & All \\
\hline 1 & 2542 & 2638 & 5180 \\
2 & 2530 & 2623 & 5153 \\
3 & 2510 & 2600 & 5110 \\
4 & 2493 & 2580 & 5073 \\
5 & 2229 & 2291 & 4520 \\
\hline & Percentages & \\
\hline 1 & 49.1 & 50.9 & 100.0 \\
2 & 49.1 & 50.9 & 100.0 \\
3 & 49.1 & 50.9 & 100.0 \\
4 & 49.1 & 50.9 & 100.0 \\
5 & 49.3 & 50.7 & 100.0 \\
\hline
\end{tabular}

Clearly the distribution of the individuals across the two groups is hardly affected by the various steps in the selection process. Table A2 gives more details about the number of spells and the exit states:

Table A2 Spells and exit states (numbers and percentages)

\begin{tabular}{|l|cc|cc|cc|}
\hline & \multicolumn{2}{|c|}{$\begin{array}{c}\text { Treatment } \\
\text { group }\end{array}$} & \multicolumn{2}{c|}{$\begin{array}{c}\text { Control } \\
\text { group }\end{array}$} & \multicolumn{2}{c|}{ All } \\
\hline Number of spells & 2229 & $(100)$ & 2291 & $(100)$ & 4520 & $(100)$ \\
Exit state: & & & & & & \\
Employment & 1852 & $(83.1)$ & 1774 & $(77.4)$ & 3626 & $(80.2)$ \\
Early retirement pay & 17 & $(0.8)$ & 28 & $(1.2)$ & 45 & $(1.0)$ \\
Study grants & 7 & $(0.3)$ & 16 & $(0.7)$ & 23 & $(0.5)$ \\
Rehabilitation benefits & 2 & $(0.1)$ & 2 & $(0.1)$ & 4 & $(0.1)$ \\
Social assistance & 6 & $(0.3)$ & 7 & $(0.3)$ & 13 & $(0.3)$ \\
Maternity pay & 34 & $(1.5)$ & 42 & $(1.8)$ & 76 & $(1.7)$ \\
Right censored & 311 & $(14.0)$ & 422 & $(18.4)$ & 733 & $(16.2)$ \\
\hline
\end{tabular}




\section{B Definitions and means of explanatory variables}

The explanatory variables used in the analysis are defined as follows:

- Male: dummy variable - reference group: female

- Age dummies: Age 30-39, Age 40-49, Age 50-59, Age 60+ years - reference group: Age < 30 years.

- Occupational dummies: Occupation 1: Academics, engineers, economists, Occupation 2: Officials, servants and salaried employees - white collar, Occupation 3: Construction, Occupation 4: Trade, Occupation 5: Self-employed, Occupation 6: Multidisciplinary, Occupation 7: Welfare workers, Occupation 8: Metal workers, Occupation 9: Food industries, Occupation 10: Other industries - reference group: Unskilled and skilled workers - blue collar.

- Dummies immigrant status: Immigrant Western, Immigrant non-Western - reference group: native Danes.

- Previous unemployment status: Continuous variables indicating the time period on public income support (0-1); Previous unemployed 1: Average degree of public income support dependence 0-1 year before unemployment spell, Previous unemployed 2: Average degree of public income support dependence 1-2 years before unemployment spell, Previous unemployed 3: Average degree of public income support dependence 2-3 years before unemployment spell

- Storstrøm County: dummy variable - reference group: South Jutland County.

- Excluded Member: dummy variable for members of treatment group, that do not participate; many of these individuals became unemployed because of bad weather and they will return to their job quickly once the weather improves - reference group: members of treatment group that participate. 
Table B1 gives an overview of the means of the explanatory variables for the treatment group and the control group. As shown means of the variables are almost identical for both groups

Table B1 Definitions and means of explanatory variables

\begin{tabular}{|l|cc|}
\hline & $\begin{array}{c}\text { Treatment } \\
\text { Group }\end{array}$ & $\begin{array}{c}\text { Control } \\
\text { Group }\end{array}$ \\
\hline Male & 0.58 & 0.57 \\
Age $<30$ & 0.24 & 0.24 \\
Age 30-39 & 0.24 & 0.26 \\
Age 40-49 & 0.26 & 0.24 \\
Age 50-59 & 0.22 & 0.24 \\
Age 60+ & 0.03 & 0.03 \\
Occupation 1 & 0.02 & 0.02 \\
Occupation 2 & 0.07 & 0.07 \\
Occupation 3 & 0.07 & 0.07 \\
Occupation 4 & 0.10 & 0.11 \\
Occupation 5 & 0.05 & 0.04 \\
Occupation 6 & 0.13 & 0.13 \\
Occupation 7 & 0.07 & 0.07 \\
Occupation 8 & 0.05 & 0.05 \\
Occupation 9 & 0.03 & 0.03 \\
Occupation 10 & 0.03 & 0.04 \\
Other occupation & 0.37 & 0.38 \\
Immigrant Western & 0.03 & 0.02 \\
Immigrant non-Western & 0.05 & 0.04 \\
Native Danes & 0.93 & 0.94 \\
Previous unemployed 1 & 0.21 & 0.20 \\
Previous unemployed 2 & 0.26 & 0.25 \\
Previous unemployed 3 & 0.26 & 0.25 \\
Storstrøm County & 0.53 & 0.53 \\
Excluded Member & 0.03 & 0.00 \\
\hline Observations & 2229 & 2291 \\
\hline
\end{tabular}

